University of New Hampshire

University of New Hampshire Scholars' Repository

$5-2006$

\title{
Observations of HONO by laser-induced fluorescence at the South Pole during ANTCI 2003
}

W Liao

Georgia Institute of Technology - Main Campus

A T. Case

Georgia Institute of Technology - Main Campus

$\mathrm{J}$ Mastromarino

Georgia Institute of Technology - Main Campus

D Tan

Georgia Institute of Technology - Main Campus

Jack E. Dibb

University of New Hampshire, jack.dibb@unh.edu

Follow this and additional works at: https://scholars.unh.edu/earthsci_facpub

Part of the Atmospheric Sciences Commons

\section{Recommended Citation}

Liao, W., A. T. Case, J. Mastromarino, D. Tan, and J. E. Dibb (2006), Observations of HONO by laserinduced fluorescence at the South Pole during ANTCI 2003, Geophys. Res. Lett., 33, L09810, doi:10.1029/ 2005 GL025470.

This Article is brought to you for free and open access by the Earth Sciences at University of New Hampshire Scholars' Repository. It has been accepted for inclusion in Earth Sciences Scholarship by an authorized administrator of University of New Hampshire Scholars' Repository. For more information, please contact Scholarly.Communication@unh.edu. 


\title{
Observations of HONO by laser-induced fluorescence at the South Pole during ANTCI 2003
}

\author{
W. Liao, ${ }^{1}$ A. T. Case, ${ }^{1}$ J. Mastromarino, ${ }^{1,2}$ D. Tan, ${ }^{1}$ and J. E. Dibb ${ }^{3}$ \\ Received 12 December 2005; revised 9 February 2006; accepted 17 February 2006; published 10 May 2006.
}

[1] Observations of nitrous acid (HONO) by laser-induced fluorescence (LIF) at the South Pole taken during the Antarctic Troposphere Chemistry Investigation (ANTCI), which took place over the time period of Nov. 15, 2003 to Jan. 4, 2004, are presented here. The median observed mixing ratio of HONO $10 \mathrm{~m}$ above the snow was $5.8 \mathrm{pptv}$ (mean value $6.3 \mathrm{pptv}$ ) with a maximum of $18.2 \mathrm{pptv}$ on Nov 30th, Dec 1st, 3rd, 15th, 17th, 21st, 22nd, 25th, 27th and 28th. The measurement uncertainty is $\pm 35 \%$. The LIF HONO observations are compared to concurrent HONO observations performed by mist chamber/ion chromatography (MC/IC). The HONO levels reported by $\mathrm{MC} / \mathrm{IC}$ are about $7.2 \pm 2.3$ times higher than those reported by LIF. Citation: Liao, W., A. T. Case, J. Mastromarino, D. Tan, and J. E. Dibb (2006), Observations of HONO by laser-induced fluorescence at the South Pole during ANTCI 2003, Geophys. Res. Lett., 33, L09810, doi:10.1029/2005GL025470.

\section{Introduction}

[2] A series of field campaigns in polar regions have spurred intense interest in the photochemistry occurring in snow. In winter at high latitudes in the Northern Hemisphere, snow can cover more than $50 \%$ of landmasses [Robinson et al., 1993]. Because snow has a large surface-to-volume ratio, it can remove atmospheric trace gases from the gas phase by adsorption, thus modifying atmospheric composition. Adsorbed gases and particulate matter can undergo heterogeneous photochemistry to release reactive trace gases back to the atmosphere. In case the snowflakes grow over co-condensation of trace gases, the snow is a potential atmospheric source through releasing the supersaturated trace gases or through sublimation. HONO plays an important role in the atmosphere due to its photodissociation by UV radiation into hydroxyl $(\mathrm{OH})$ and nitric oxide (NO) radicals; a number of measurements [Dibb et al., 2002; Zhou et al., 2001] report elevated HONO concentrations, sometimes much higher than can be accounted for in photochemistry models. The high levels of HONO reported often lead to a dramatic over-prediction of $\mathrm{HO}_{\mathrm{x}}$ [Davis et al., 2004], and sometimes $\mathrm{NO}_{\mathrm{x}}$ [Dibb et al., 2004], which are difficult to reconcile with concurrent measurements of $\mathrm{OH}, \mathrm{HO}_{2}$ and $\mathrm{NO}$. These results raised possible missing sinks for $\mathrm{HO}_{\mathrm{x}}$ and $\mathrm{NO}_{\mathrm{x}}$ or, alternatively, problems

\footnotetext{
${ }^{1}$ Earth and Atmospheric Sciences, Georgia Institute of Technology, Atlanta, Georgia, USA.

${ }^{2}$ Now at Applied Technology Associate, Albuquerque, New Mexico, USA.

${ }^{3}$ Climate Change Research Center, University of New Hampshire, Durham, New Hampshire, USA.
}

Copyright 2006 by the American Geophysical Union. 0094-8276/06/2005GL025470 with the HONO measurements. Quantifying the amount of HONO emitted by snowpack is important for the global photochemistry budget and a deeper understanding of the heterogeneous processes involving snowpack and aerosol particles is necessary.

[3] In principle, heterogeneous processes can deplete the concentration of gas phase species through adsorption and subsequently increase their concentrations through removal processes from reservoir species. Adsorption on ice may be an important removal process of $\mathrm{HNO}_{3}$, of some importance for $\mathrm{HONO}$ and peroxyacetyl nitrate (PAN), but apparently irrelevant for $\mathrm{NO}$ and $\mathrm{NO}_{2}$ [Bartels-Rausch et al., 2002]. As gas-snow partitioning changes with temperature, emission from or deposition to the snowpack may change with strong temperature changes. Temperature changes are generally associated with changes in meteorological conditions: changes in wind speed and wind direction may affect snowpack ventilation and therefore atmospheric concentrations of HONO and other reactive nitrogen species. There seems to be agreement that the nitrate photolysis within the snowpack is the dominant origin of $\mathrm{NO}_{\mathrm{x}}$ and $\mathrm{HONO}$ in the polar atmospheric boundary layer [Honrath et al., 2000].

[4] Because of its short lifetime with respect to photolysis, snowpack emissions of HONO remain confined to a thin layer near the surface, where HONO can give rise to significant production of $\mathrm{OH}$ radicals in polar regions [Domine and Shepson, 2002]. Honrath et al. [2002] showed that the 24-hour average $\mathrm{NO}_{\mathrm{x}}$ and $\mathrm{HONO}$ emission rates at Summit, Greenland during the summer of 2000 were approximately 4 times the $\mathrm{HNO}_{3}$ deposition rates, indicating that $\mathrm{NO}_{\mathrm{x}}$ export may slowly remove nitrogen from the boundary layer in summer time. In remote polar regions, snowpack photochemistry provides a way to remobilize deposited $\mathrm{HNO}_{3}$, thereby influencing $\mathrm{NO}_{\mathrm{x}}$ photochemistry. The Investigation of Sulfur Chemistry in the Antarctic Troposphere (ISCAT) 1998 and 2000 observed NO levels exceeding those at other polar sites by nearly an order of magnitude. On ISCAT 2000, HONO was measured by mist chamber. However, the observed median HONO concentration of 25 pptv (see Table 1) was too high to reconcile with models of the $\mathrm{HO}_{\mathrm{x}}$ and $\mathrm{NO}_{\mathrm{x}}$ budget [Davis et al., 2004]. This led to great interest to go back to South Pole to measure HONO using an alternative technique.

[5] Current HONO measurements are: differential optical absorption spectroscopy (DOAS) [Alicke et al., 2003] and laser-induced fluorescence (LIF) [Liao et al., 2006] which are based on spectroscopy; converting $\mathrm{HONO}$ to $\mathrm{NO}_{2}^{-}$and analyzing the nitrite by mist chamber/ion chromatography (MC/IC) [Dibb et al., 2002] or the photometric detection of an azo dye derivative by long path absorption photometer (LOPAP) [Heland et al., 2001]; aqueous scrubbing using a coil sampler followed by 2,4-dinitrophenylhydrazine 
Table 1. Comparison of Existing Results of HONO Measurements 10 Meters Above Snow at South Pole, Both MC/IC Measurements Were Reported by Dibb

\begin{tabular}{lccc}
\hline & & \multicolumn{2}{c}{2003 Nov } \\
& 2000 Dec 27th & \multicolumn{2}{c}{ 30th-Dec 1st } \\
\cline { 2 - 5 } MC/IC & MC/IC & LIF \\
\hline Median HONO (pptv) & 25 & 55 & 10 \\
\hline
\end{tabular}

(DNPH) derivatization and determining the complex by high-performance liquid chromatographic (HPLC) analysis [Zhou et al., 1999]; and the diffusion-based denuder/ion chromatography system [Acker et al., 2005].

[6] Here we provide observations from ambient $\mathrm{HONO}$ measurements during ANTCI 2003 in the austral summer. The Antarctic Troposphere Chemistry Investigation (ANTCI) is a four year program including two major field studies (2003 and 2005) in Antarctica. The major science objectives are to evaluate the physical and chemical processes of nitrogen oxides and hydrogen oxides; to compare boundary layer measurements of South Pole with other regions of Antarctica; and to investigate the importance and location of the coast-to-plateau transport of sulfur.

\section{Experiments}

[7] Ambient measurements were conducted at the Atmospheric Research Observatory (ARO) at South Pole during ANTCI in November and December of 2003. One face of the ARO held the in situ experimental probes and faced the clean air sector, a zone between grid 360-110 degrees extending $148 \mathrm{~km}$ from South Pole and $2 \mathrm{~km}$ above the snow surface. The clean air sector has a very long fetch into the mean katabatic flow from the Antarctic Plateau.

[8] The photo fragmentation/laser-induced fluorescence (PF-LIF) technique was used to measure atmospheric HONO 10 meters above the surface. Figure 1 presents a schematic illustration of the PF-LIF HONO detection system. A detailed description of the method is provided by Liao et al. [2006]. Briefly, ambient air is drawn into the sample cell at $30 \mathrm{~L} / \mathrm{min}$ through a $1 / 2^{\prime \prime}$ I.D. teflon tube $\sim 2.5$ $\mathrm{m}$ long extending about $10 \mathrm{~cm}$ outside the wall of the ARO facing the clean air sector. The first $30 \mathrm{~cm}$ of the inlet tube was maintained at $\sim 297 \mathrm{~K}$. The residence time in the inlet was $\sim 0.5 \mathrm{~s}$. There was no significant difference in signal whether the inlet heater was turned off or not, indicating that inlet surface reactions were not important in the very dry conditions found in ANTCI. HONO in the sample cell is photo fragmented at $355 \mathrm{~nm}$ with the third harmonic of a YAG laser and the generated $\mathrm{OH}$ radical is probed at 282 $\mathrm{nm}$; the photolysis beam alternately precedes and follows the $\mathrm{OH}$ probe beam, automatically accounting for ambient as well as any instrument-generated $\mathrm{OH}$; the excited state $\mathrm{OH}$ fluorescence at $309 \mathrm{~nm}$ is detected by photomultiplier tube. This detection scheme is direct, fast, and free from identifiable interferences, including hydrogen peroxide, nitric acid, and pernitric acid. The system was calibrated by standard addition every 3 hours. A 1 slpm flow of dry nitrogen was passed over constant mixing of $\mathrm{NaNO}_{2}$ and $\mathrm{H}_{2} \mathrm{SO}_{4}$ solutions to generate standard additions of $\mathrm{HONO}$ (typically 12 to $50 \mathrm{pptv}$ ). The HONO standard addition concentration was verified by laboratory UV/VIS differen- tial optical absorption spectroscopy. The 2- $\sigma$ detection limit of the technique was typically 2-3 parts per trillion by volume (pptv) for HONO, with a sample integration time of 10 minutes. The relative uncertainty was estimated to be about $\pm 35 \%$, driven largely by calibration uncertainty and laser power fluctuations. Measurements were typically taken for the 12 hours per day that the inlet was over sunlit snow.

\section{Results}

[9] HONO was measured in the ARO on Nov 30th, Dec 1st, 3rd, 15th, 17th, 21st, 22nd, 25th, 27th and 28th (Figure 2 (top)). The median mixing ratio of HONO $10 \mathrm{~m}$ above the snow in this period was 5.8 pptv (6.3 pptv mean), reaching a maximum value of $18.2 \mathrm{pptv}$ on Dec $1 \mathrm{st}$. We see the highest concentrations at the end of November; a period marked by cold temperatures, and a shallow boundary layer. NO levels (shown in Figure 2 and taken to be representative of other surface-emitted species) measured in the ARO at this time are also highly elevated, indicating surface emissions into a small mixing volume. HONO levels decrease in early December, when the boundary layer is relatively deep; NO levels in this time period are relatively low. HONO levels increase again around December 22nd, a period also marked by high levels of $\mathrm{NO}, \mathrm{HNO}_{3}$, and $\mathrm{HNO}_{4}$. The HONO levels we report here by LIF are lower than previous observations reported by MC/IC from ISCAT 2000 [Dibb et al., 2004] and much lower than concurrent MC/IC measurements (Table 1). Figure 3 shows HONO levels for Dec 1st showing the typical variability over the 12 hour measurement period. Since there was no night during ANTCI 2003, diurnal variability is driven largely by wind direction, presence of cloud cover, and presumably snow-phase chemistry.

[10] Because NO is both a gas-phase precursor to HONO and a photolysis product, it may be interesting to compare the behavior of these two species. Overall, the median HONO to NO ratio is $2 \%$, except for the last two days when the ratio increased to $10 \%$. The correlation between the two, however, is poor (Figure 4). The poor correlation $\left(r^{2}=0.17\right)$ is not surprising, however, given that the median lifetime of $\mathrm{NO}_{\mathrm{x}}$ at ANTCI was 13 hours, whereas the

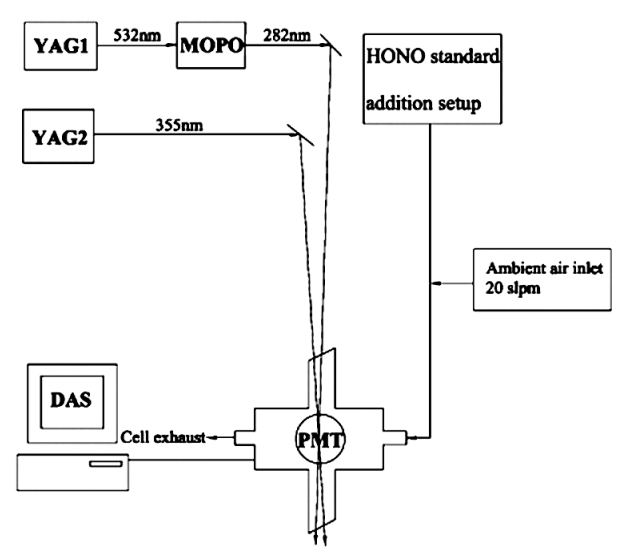

Figure 1. LIF HONO measurement instrumentation (MOPO: Master Oscillator/Power Oscillator, PMT: Photomultiplier Tube, DAS: Data Acquisition System). 




Figure 2. Temporal plot of HONO (pptv), NO (pptv), Temperature (K) and Boundary Layer Height (m). Observed HONO mixing ratio was at $10 \mathrm{~m}$ above the snow at South Pole on Nov 30th, Dec 1st, 3rd, 15th, 17th, 21st, 22nd, 25th, 27th and 28th during ANTCI 2003.The highest line in the Boundary Layer Height panel is $180 \mathrm{~m}$, which indicates that data were collected and analyzed for mixed layer depth but none was found. The maximum range of the sodar deployed was $175 \mathrm{~m}$.

median lifetime for HONO was only 6 minutes. HONO will be much more sensitive than NO to local conditions and less sensitive to chemistry upwind. Furthermore, the snow emission chemistry is complex and involves heterogeneous processes and interstitial photochemistry. Factors could influence the $\mathrm{HONO}$ source like $\mathrm{HNO}_{3}$ deposition rate, rate of photolysis of $\mathrm{NO}_{3}^{-}$and $\mathrm{NO}_{2}^{-}, \mathrm{pH}$ of snow, wind speed, solar radiation etc. If photolysis of nitrate $\left(\mathrm{NO}_{3}^{-}\right)$is the dominant source of $\mathrm{HONO}$, and the HONO generation is the secondary step through $\mathrm{NO}_{2}^{-}$. $\mathrm{NO}_{2}^{-}$photolysis is considerably faster than that of $\mathrm{NO}_{3}^{-}$; depending on properties such as the temperature dependence of the snow-phase reactions, partitioning and quantum yield of the involved processes, $\mathrm{NO}, \mathrm{NO}_{2}$, or $\mathrm{HONO}$ may be dominant products. It is neither expected nor necessary that the $\mathrm{NO} / \mathrm{HONO}$ ratio be fixed.

[11] HONO was also measured by mist chamber/ion chromatography analysis $(\mathrm{MC} / \mathrm{IC})$ of the $\mathrm{NO}_{2}^{-}$ion by the University of New Hampshire [Dibb et al., 1994, 2002]. Most of the MC/IC measurements were taken at the snow surface adjacent to the ARO; however, MC/IC HONO data for Nov 30th and Dec $1 \mathrm{st}$ at $10 \mathrm{~m}$ in the ARO are also available. The MC/IC observed HONO levels at both the surface and from the ARO are significantly higher than the PF-LIF observations, and also higher than was reported in ISCAT 2000. There is no noticeable trend in MC/IC surface versus $10 \mathrm{~m}$ data, at least for the two days $\mathrm{MC} / \mathrm{IC}$ data are available from the ARO. Overall, MC/IC HONO data from ANTCI 2003 were $7.2 \pm 2.3$ times higher than LIF HONO data (Figure 5) with no correlation $\left(\mathrm{r}^{2}\right.$ is 0.017$)$.

[12] At present we do not have a definitive explanation for the large discrepancy found in ANTCI between measurement techniques. An intercomparison of the two techniques at $10 \mathrm{~m}$ was unsuccessful: the median HONO mixing ratio at $10 \mathrm{~m}$ for the intercomparison period by $\mathrm{MC} / \mathrm{IC}$ is $55 \mathrm{pptv}$, while that by LIF is 10 pptv. Exchange of calibration standards was also unsuccessful: the LIF calibration source produced interferences for the $\mathrm{MC} / \mathrm{IC}$ measurement not observable by LIF, and the $\mathrm{MC} / \mathrm{IC}$ source (dissolved nitrite) was not suitable for the gas-phase LIF

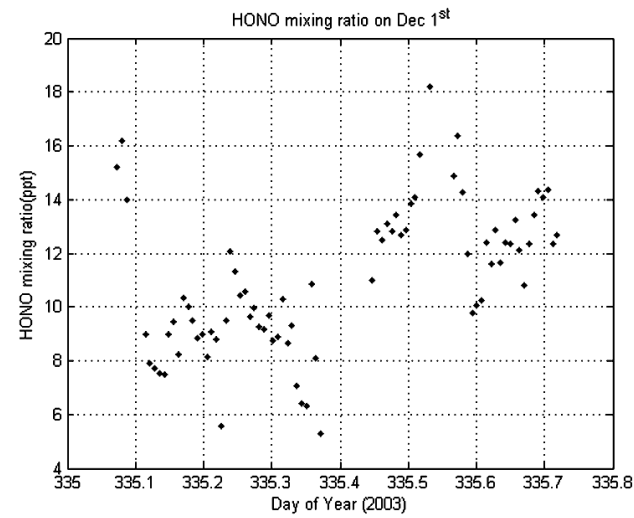

Figure 3. HONO observations on Dec 1st, $200310 \mathrm{~m}$ above the snow at South Pole.

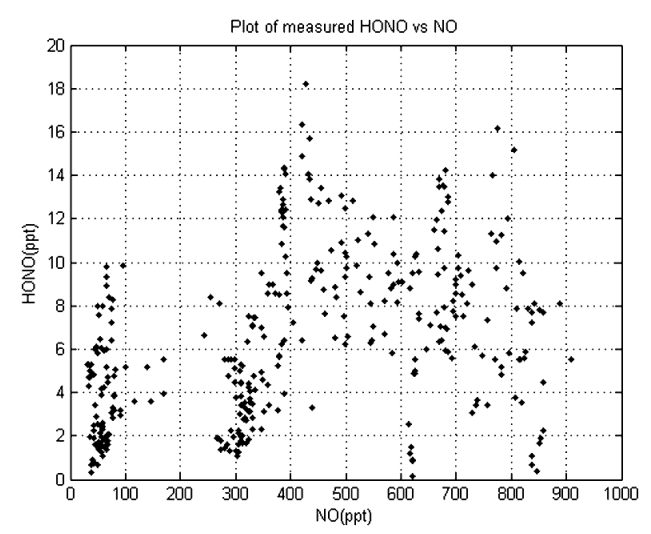

Figure 4. Scatterplot of the mixing ratio of HONO versus NO. The correlation is very poor $\left(\mathrm{r}^{2}=0.17\right)$. 


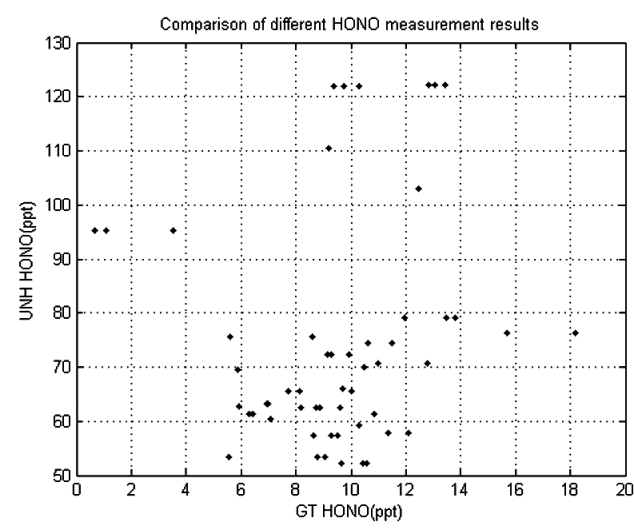

Figure 5. Comparison of different HONO measurements (UNH: MC/IC; GT: LIF) $\left(\mathrm{r}^{2}=0.017\right)$.

measurement. It should also be noted that concurrent LIF and $\mathrm{MC} / \mathrm{IC}$ HONO data are limited, further complicating a detailed assessment of the differences. It is possible that the $\mathrm{MC} / \mathrm{IC}$ technique might suffer from interference from $\mathrm{HNO}_{4}$. During the intercomparison period, the MC/IC HONO observations appeared to track the sum of LIF $\mathrm{HONO}$ and $\mathrm{HNO}_{4}$ as measured by CIMS (S. Sjosted, personal communication, 2005). We also cannot rule out the possibility that the LIF measurement was actually less sensitive than reported. Possible other reasons for this discrepancy include the different inlets and time scales used for the two techniques which could result in adsorption of HONO, heterogeneous hydrolysis of $\mathrm{NO}_{2}$ or positive interferences from $\mathrm{NO}_{2}$ - or other nitrogen oxides, in particular pernitric acid.

\section{Conclusions}

[13] The ANTCI 2003 measurements confirm the high HONO levels observed previously in ISCAT 2000 (Table 1), although there is significant discrepancy in the HONO measurements by LIF and MC/IC. Both the LIF and MC/ IC techniques observed higher than expected levels of HONO; however, the MC/IC observations were higher than the LIF observations by a factor of $7.2 \pm 2.3$ in the median. HONO as measured by both techniques roughly follow NO levels and scale inversely with boundary layer height. A number of factors could influence the HONO concentrations observed during ANTCI, including the $\mathrm{HNO}_{3}$ deposition rate, the rate of photolysis of snow-phase $\mathrm{NO}_{3}^{-}$and $\mathrm{NO}_{2}^{-}$, the $\mathrm{pH}$ of snow, wind speed, and solar radiation. A modeling effort (beyond the scope of this observational paper) is presently underway to understand HONO during
ANTCI, including the possible snow HONO source and the effect of $\mathrm{HONO}$ on $\mathrm{HO}_{\mathrm{x}}$.

[14] Acknowledgments. We would like to thank the participants of the ANTCI 2003 experiment, especially to Fred Eisele and Lee Mauldin for their constructive suggestions. Funding for this project was received from the National Science Foundation award ATM 0230246.

\section{References}

Acker, K., D. Moller, R. Auel, W. Wieprecht, and D. Kalass (2005), Concentrations of nitrous acid, nitric acid, nitrite and nitrate in the gas and aerosol phase at a site in the emission zone during ESCOMPTE 2001 experiment, Atmos. Res., 74, 507-524.

Alicke, B., A. Geyer, A. Hofzumahaus, F. Holland, S. Konrad, H. W. Pätz, J. Schäfer, J. Stutz, A. Volz-Thomas, and U. Platt (2003), OH formation by HONO photolysis during the BERLIOZ experiment, J. Geophys. Res., 108(D4), 8247, doi:10.1029/2001JD000579.

Bartels-Rausch, T., B. Eichler, P. Zimmermann, H. W. Gaggeler, and M. Ammann (2002), The adsorption enthalpy of nitrogen oxides on crystalline ice, Atmos. Chem. Phys., 2, 235-247.

Davis, D. D., et al. (2004), An overview of ISCAT 2000, Atmos. Environ., $38,5363-5373$.

Dibb, J. E., R. W. Talbot, and M. H. Bergin (1994), Soluble acidic species in air and snow at Summit, Greenland, Geophys. Res. Lett., 21, $1627-$ 1630.

Dibb, J. E., M. Arsenault, M. C. Peterson, and R. E. Honrath (2002), Fast nitrogen oxide photochemistry in Summit, Greenland snow, Atmos. Environ., 36, 2501-2511.

Dibb, J. E., L. G. Huey, D. L. Slusher, and D. J. Tanner (2004), Soluble reactive nitrogen oxides at South Pole during ISCAT 2000, Atmos. Environ., 38, 5399-5409.

Domine, F., and P. B. Shepson (2002), Air-snow interactions and atmospheric chemistry, Science, 297, 1506-1510.

Heland, J., J. Kleffmann, R. Kurtenbach, and P. Wiesen (2001), A new instrument to measure gaseous nitrous acid (HONO) in the atmosphere, Environ. Sci. Technol., 35, 3207-3212.

Honrath, R. E., M. C. Peterson, M. P. Dziobak, J. E. Dibb, M. A. Arsenault, and S. A. Green (2000), Release of $\mathrm{NO}_{x}$ from sunlight-irradiated midlatitude snow, Geophys. Res. Lett., 27, 2237-2240.

Honrath, R. E., Y. Lu, M. C. Peterson, J. E. Dibb, M. A. Arsenault, N. J. Cullen, and K. Steffen (2002), Vertical fluxes of $\mathrm{NO}_{x}, \mathrm{HONO}$, and $\mathrm{HNO}_{3}$ above the snowpack at Summit, Greenland, Atmos. Environ., 36, 26292640 .

Liao, W., A. Hecobian, J. Mastromarino, and D. Tan (2006), Development of a photo-fragmentation/laser-induced fluorescence measurement of atmospheric nitrous acid (HONO), Atmos. Environ., 40, 17-26.

Robinson, D. A., K. F. Dewey, and R. R. Heim (1993), Global snow cover monitoring: An update, Bull. Am. Meteorol. Soc., 74, 1689-1696.

Zhou, X. L., H. C. Qiao, G. H. Deng, and K. Civerolo (1999), A method for the measurement of atmospheric HONO based on DNPH derivatization and HPLC analysis, Environ. Sci. Technol., 33, 3672-3679.

Zhou, X. L., H. J. Beine, R. E. Honrath, J. D. Fuentes, W. Simpson, P. B. Shepson, and J. W. Bottenheim (2001), Snowpack photochemical production of HONO: A major source of $\mathrm{OH}$ in the Arctic boundary layer in springtime, Geophys. Res. Lett., 28, 4087-40930.

A. T. Case, W. Liao, and D. Tan, Earth and Atmospheric Sciences, Georgia Institute of Technology, Atlanta, GA 30332, USA. (dtan@eas. gatech.edu)

J. E. Dibb, Climate Change Research Center, University of New Hampshire, Durham, NH 03824, USA.

J. Mastromarino, Applied Technology Associate, Albuquerque, NM 87111, USA. 